\title{
Tumours of the retinal pigment epithelium
}

\author{
ALEG GARNER \\ Department of Pathology, Institute of Ophthalmology, University of London
}

Under normal circumstances there is little, if any, turnover of the pigment epithelium of the human retina, and this absence of opportunity for aberrant genetic mutations to occur may in part account for the rarity of neoplasia in this tissue. Moreover, in those rare instances where tumours have developed, they have not infrequently been preceded by a hyperplastic proliferation associated with chronic choroido-retinitis. To what extent such neoplasms can ever be regarded as malignant has been the subject of some debate, and Fair (1958) concluded that it was perhaps best to leave the question open until more cases had been presented for study.

Over a space of 20 years three such tumours have been diagnosed in the Department of Pathology at the Institute of Ophthalmology, one of them having been previously reported by Greer (1952). It is the purpose of this present report to describe the pathology of the remaining two, as well as to comment on the prognostic implications of the histological findings in this type of neoplasm.

\section{Case reports}

Case I (44893/64), an I I-year-old girl

CLINICAL HISTORY

The patient first presented with progressive blurring of vision and pain in the right eye of one month's duration. She was found to have acute glaucoma associated with a complete retinal detachment which was displacing the iris in an anterior direction. Post-inflammatory Coats's disease was diagnosed and though for a time the glaucoma was controlled by corticosteroid administration, enucleation had eventually to be performed 13 months after the onset of symptoms.

PATHOLOGY

Macroscopically the eye was phthisical with disorganization of its contents.

Histological examination showed the iris to be foreshortened with a slender fibrous membrane extending across the pupil and on to the front of the iris, where it was associated with peripheral synechiae formation and closure of the filtration angle. The trabecular meshwork was sclerosed. Posterior synechiae were also present between the iris and the lens capsule and there was a partial cyclitic membrane. Both the iris and the ciliary body showed moderate lymphocytic and plasma cell infiltration. Ringschwiele, in which considerable proliferation of the pigment epithelium of the peripheral retina was seen, was a prominent feature and was associated with almost total retinal 
detachment. The retina itself was degenerate and atrophic while the entire subretinal space was filled by a large essentially non-pigmented tumour (Fig. I).

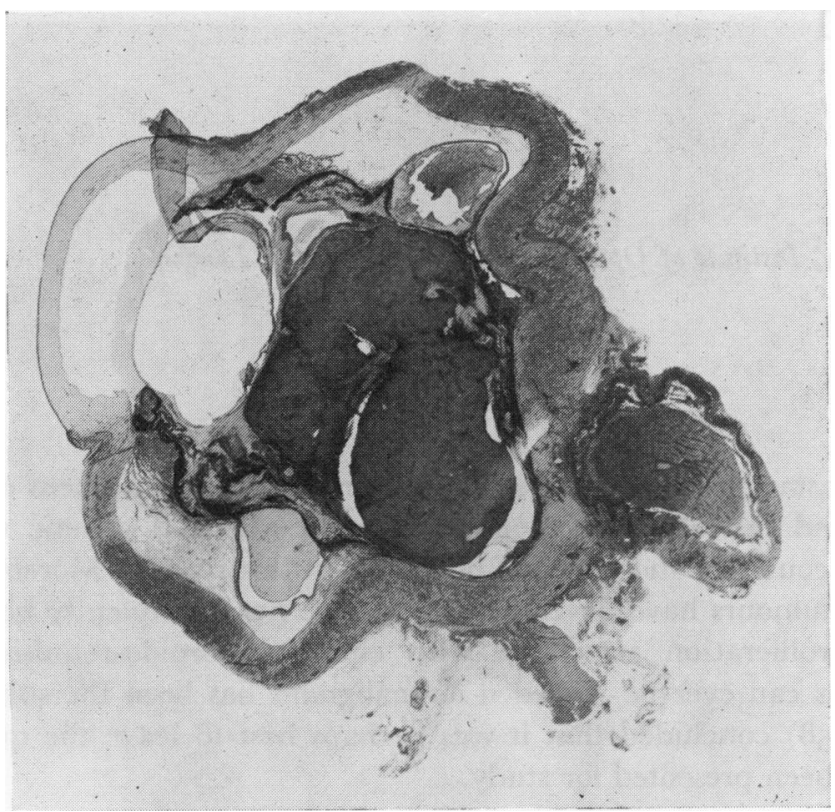

FIG. I Case I. The eye is phthisical with post-inflammatory synechiae in the anterior segment, proliferation of the pars plana and retinal pigment epithelium, choroidal fibrosis, ringschwiele, and extensive retinal detachment. $A$ solid unpigmented tumour mass fills the subretinal space. Haematoxylin and eosin. $\times 4$

Composed of polygonal cells with generally ill-defined cytoplasmic outlines and pale-staining nuclei in which nucleoli were prominent (Figs 2 and 3), the tumour was considered to have originated in the pigment epithelium of the retina; there was little evidence of adenomatous differentiation, the cells being arranged in sheets and solid cords. In addition to the neoplastic proliferation, the tumour was surrounded by some heavily-pigmented hyperplastic retinal epithelium, where it was in contact (2)

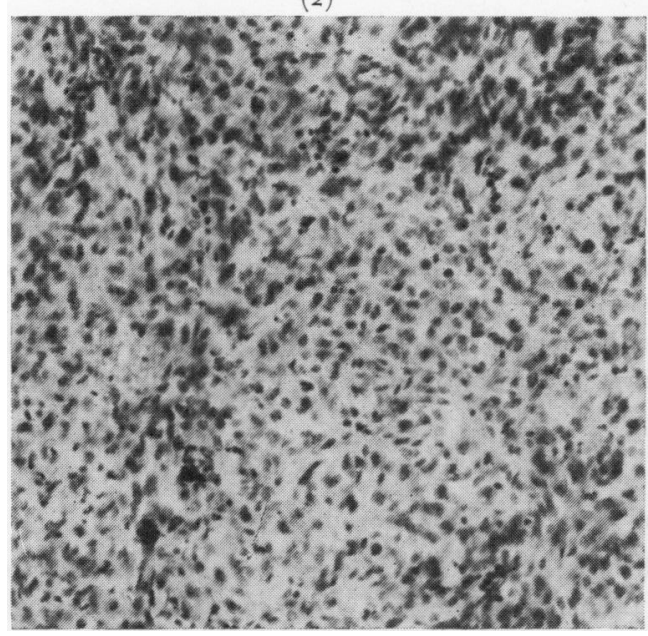

(3)

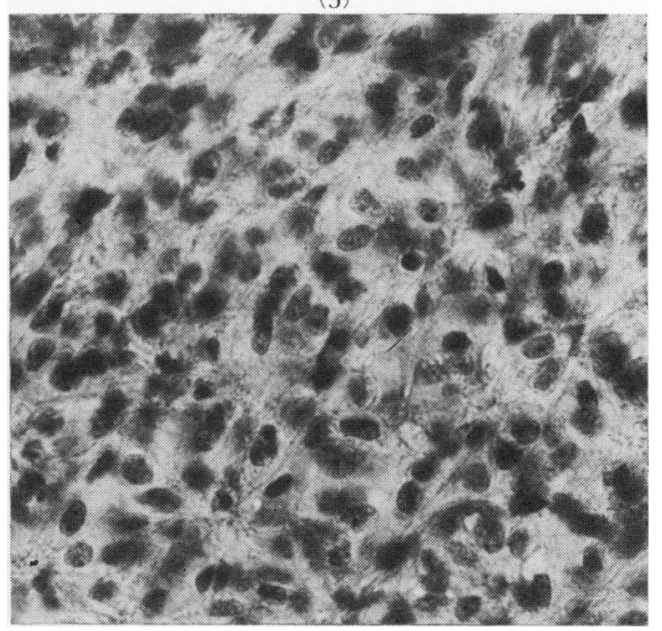

FIG. 2 Case I. The tumour consists of sheets of randomly-orientated unpigmented cells. Haematoxylin and eosin. $\times 150$

FIG. 3 Case I. At higher magnification the tumour cells are seen to have ill-defined cytoplasmic borders and round or ovoid nuclei in which nucleoli are discernible. Haematoxylin and eosin. $\times 375$ 
with a disorganized choroid in which lymphocytic infiltration, scar tissue, and bone were prominent. Whether choroidal invasion by the tumour had occurred could not be determined, since the boundary between the choroid and retina had been obliterated by the inflammatory process. The sclera was not involved.

S U M M A R Y

Chronic uveitis leading to phthisis bulbi. Tumour of the retinal pigment epithelium.

FOLLOW-UP

There has been no sign of recurrence or metastasis and the patient was alive and well some $5 \frac{1}{2}$ years later.

Case 2 (42389/69), a 4 1-year-old female

CLINICAL HISTORY

The patient was referred to Moorfields Hospital on October 30, 1969, with a 6 months' history of slight blurring of vision and micropsia in the left eye. She had also complained of "floaters" in this eye for 6 years. Examination revealed a small pigmented mass in the equatorial region of the inferior hemisphere, which had broken through the retina and given rise to what were presumed to be tumour cells in the vitreous. Similar cells were also present in the anterior chamber. A diagnosis of malignant melanoma was made and the eye was enucleated as a matter of urgency 2 days later.

\section{PATHOLOGY}

No external abnormality was seen on gross inspection. The opened globe showed a pigmented tumour in the equatorial part of the infero-nasal quadrant, apparently arising from the choroid (Fig. 4).

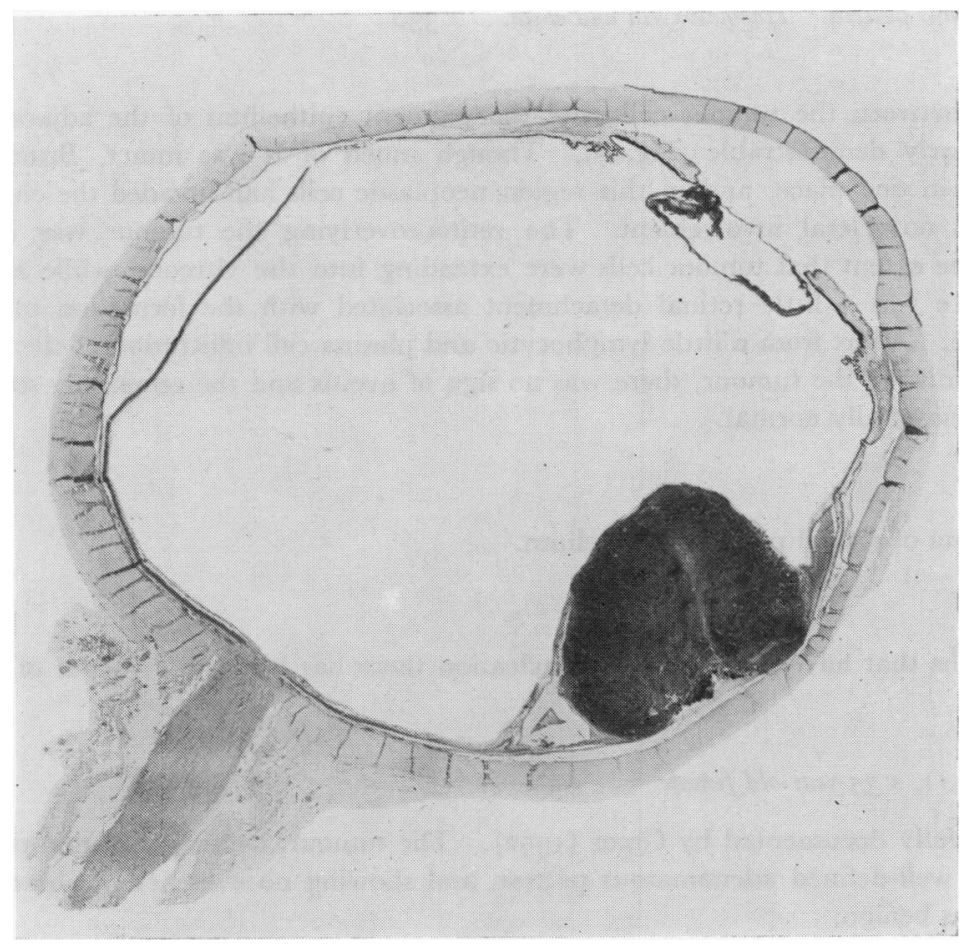

FIG. 4 Case 2. Immediately behind the equator in the lower part of the fundus there is a pigmented tumour mass which is in direct contact with the vitreous. Haematoxylin and eosin. $\quad \times 4$ 
Histologically the tumour was composed of more or less regular cuboidal or low columnar cells which generally had abundant cytoplasm and a quite heavy content of finely granular melanin pigment (Figs 5 and 6).
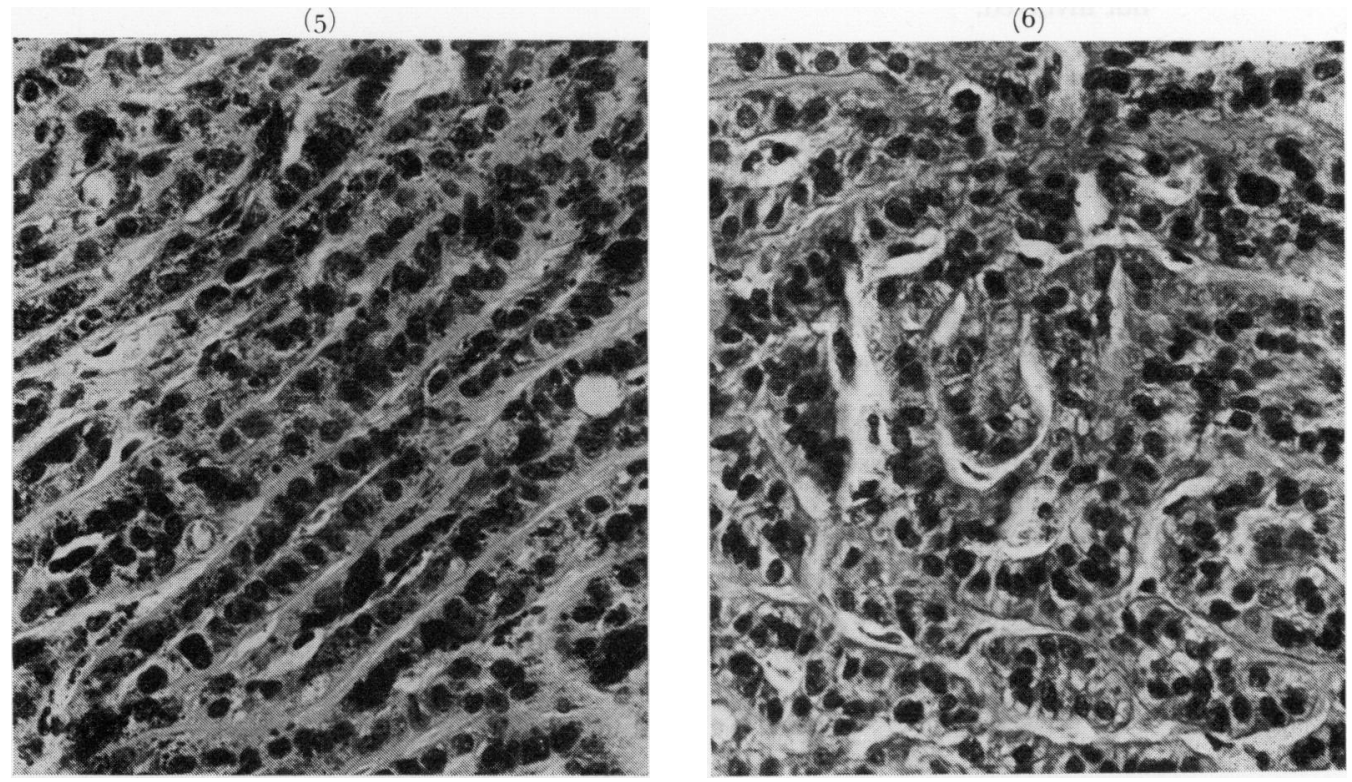

FIG. 5 Case 2. The tumour cells are arranged in a tubular fashion, are mostly cuboidal, and contain fine granules of melanin. Haematoxylin and eosin. $\times 330$

FI G. 6 Case 2. Bleached section, showing neoplastic cells of cuboidal or low columnar type grouped in a welldefined adenomatous pattern. Haematoxylin and eosin. $\times 33^{\circ}$

Continuity between the tumour cells and the pigment epithelium of the adjacent uninvolved retina was clearly demonstrable (Fig. 7). Though much of it was intact, Bruch's membrane was destroyed in one place, and in this region neoplastic cells had invaded the choroid (Fig. 8), but there was no scleral involvement. The retina overlying the tumour was infiltrated and destroyed to the extent that tumour cells were extending into the vitreous, while at the edges of the lesion there was a little retinal detachment associated with the formation of a serous subretinal exudate. Apart from a little lymphocytic and plasma cell infiltration of the choroid in the immediate vicinity of the tumour, there was no sign of uveitis and the remaining structures of the eye appeared essentially normal.

SUMMARY

Adenocarcinoma of retinal pigment epithelium.

FOLLOW-UP

In the 9 months that have elapsed since enucleation there has been no evidence of recurrence or metastasis.

Case 3 (1 7830/51), a 35-year-old female

This case was fully documented by Greer (1952). The tumour, consisting of non-pigmented cells arranged in a well-defined adenomatous pattern and showing no evidence of choroidal invasion, was regarded as benign. 
FOLLOW-UP

Subsequent enquiry by the departmental tumour registry revealed that the patient, aged 35 years at the time of enucleation, was alive and well 16 years later.

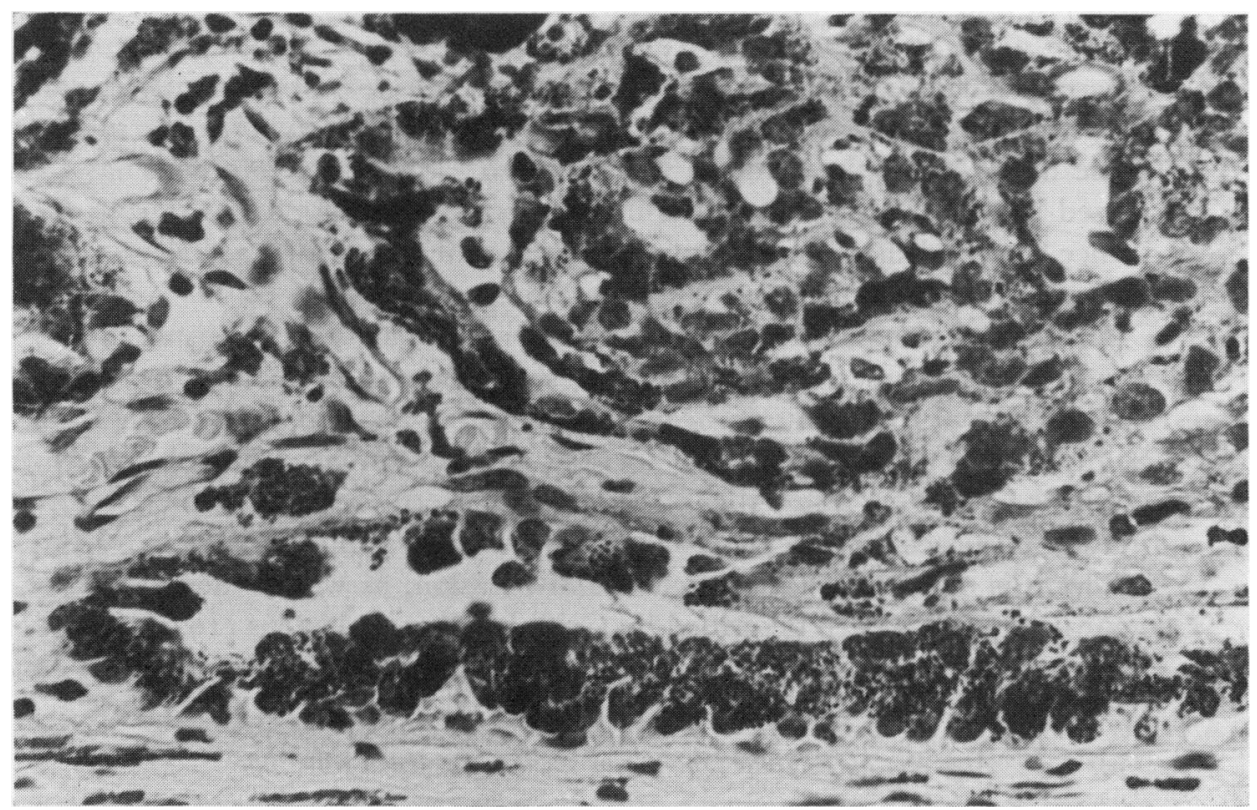

FIG. 7 Case 2. Section showing continuity between the tumour and an intact single layer of normal pre-existing retinal pigment epithelium. Haematoxylin and eosin. $\times 500$

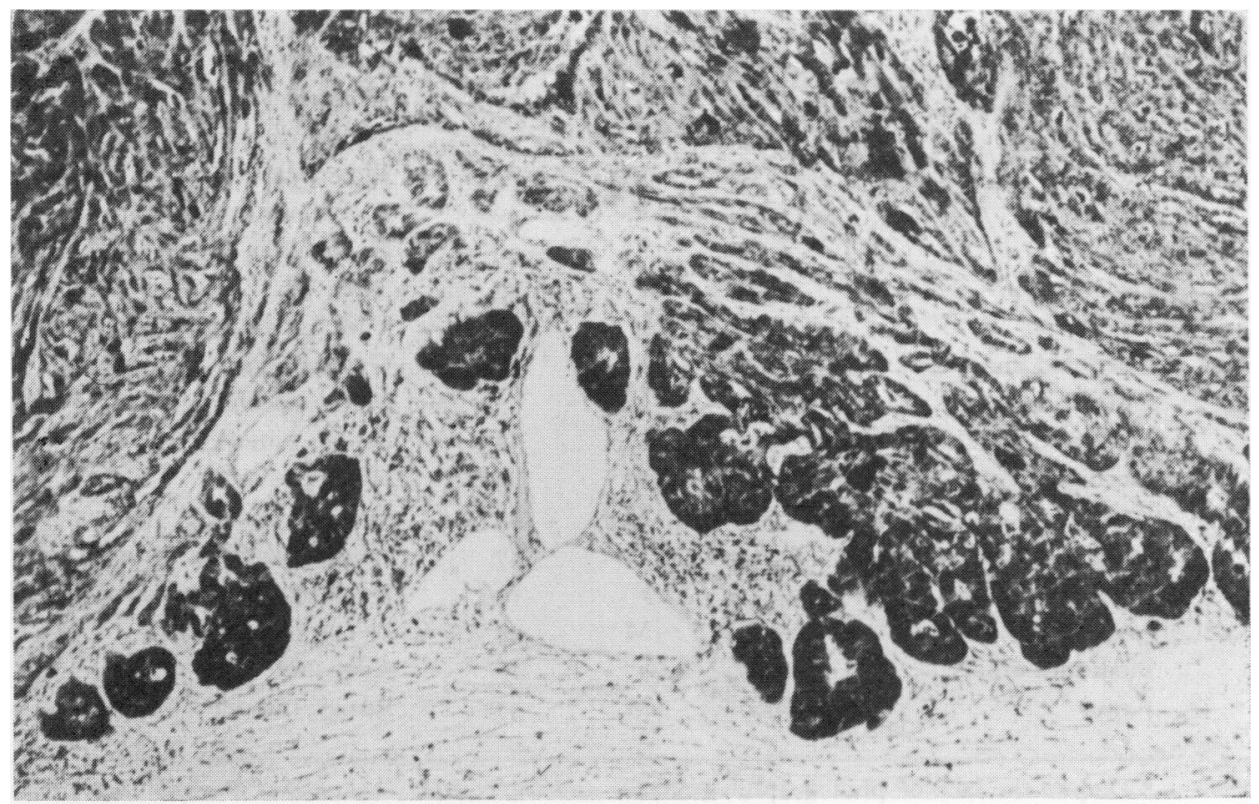

FIG. 8 Case 2. Section demonstrating invasion of the choroid by islands of heavily-pigmented tumour cells showing a clearly-defined acinar arrangement. Haematoxylin and eosin. $\times 80$ 


\section{Discussion}

Difficulty in the interpretation of tumours of the retinal pigment epithelium arises from? doubts as to the significance of such ostensibly malignant factors as evidence of choroidal

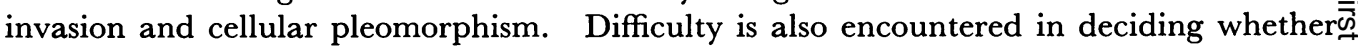
the proliferating epithelium is truly neoplastic, in the sense that it has undergone a change whereby "the normal growth-controlling mechanism is permanently impaired, permitting progressive growth" (Berenblum, 1970), or whether it is hyperplastic in that growth would ${ }_{\bar{\Phi}}$ cease if and when the stimulus was removed. The latter problem has already been discussed by Greer (1952) and it is not necessary to reiterate the reasons for the difficulty; suffice it to add that it only serves to confuse the issue when authors use the term primary: hyperplasia to describe a benign neoplasm.

Malignant tumours are characterized by a capacity to metastasize and to invade the surrounding tissues. In none of the retinal pigment epithelium tumours so far reported? has the first of these criteria been demonstrated, apart possibly from a case described by Schuster (1928), in which the identity of the primary tumour was not convincingly $\overrightarrow{-}$ established, and an attested case reported by Bietti (I93I), in which unfortunately confirmation of suspected liver metastasis by necropsy was not permitted. Even so, the secondo criterion is equally valid, and choroidal invasion, as well as destruction of the overlyingneuro-retina, has been described by Griffith (I894), Märtens (I92 I), Bietti (I93 I), Rønne Z (1945), Fair (1958), Cury, Lucic, and Irvine (1959), Rein (1960), Kurz and Zimmermanळ

Table I Analysis of reported tumours of retinal pigment epithelium

\begin{tabular}{|c|c|c|c|}
\hline Authors & Date & Sex & $\begin{array}{l}\text { Age } \\
(y r s)\end{array}$ \\
\hline Present report & I970 & $\mathbf{F}$ & 12 \\
\hline Present report & 1970 & $\mathbf{F}$ & $4^{I}$ \\
\hline Griffith* & I 894 & $\mathbf{M}$ & 37 \\
\hline Märtens & 1921 & $\mathbf{F}$ & 46 \\
\hline Bietti & I931 & $\mathbf{M}$ & 63 \\
\hline Rønne & I945 & $\mathbf{F}$ & 40 \\
\hline Stow & I 949 & $\mathbf{M}$ & 49 \\
\hline Greer & 1952 & $\mathbf{F}$ & 35 \\
\hline Fairt & 1958 & $\mathbf{F}$ & 26 \\
\hline Theobald and others & $195^{8}$ & $\mathbf{F}$ & I I \\
\hline Cury and others $\ddagger$ & I959 & $\mathbf{M}$ & 5 \\
\hline Duke and Maumenee & I959 & $\mathbf{M}$ & 39 \\
\hline Kornblueth and Behar & 1960 & $\mathbf{M}$ & 80 \\
\hline Rein & 196o & $\mathbf{M}$ & 55 \\
\hline Kurz and Zimmerman & 1962 & $\mathbf{F}$ & 57 \\
\hline Spiers and Jensen & 1963 & $\mathbf{F}$ & Io \\
\hline Machemer & 1964 & $\mathbf{M}$ & 29 \\
\hline Blodi and others & 1965 & $\mathbf{F}$ & 76 \\
\hline Kraus & I 968 & $\mathbf{M}$ & 37 \\
\hline
\end{tabular}

\begin{tabular}{l} 
Author's diagnosis \\
\hline Adenoma \\
Adenocarcinoma \\
Malignant tumour \\
Malignant epithelioma \\
Melanocarcinoma \\
Malignant tumour \\
Hyperplasia \\
Adenoma \\
? Malignant tumour \\
Hyperplasia \\
Malignant melanoma \\
Benign tumour \\
Hyperplasia \\
Primary tumour \\
Adenocarcinoma \\
Pseudoepitheliomatous hyperplasia \\
Primary hyperplasia \\
Adenoma \\
Benign tumour
\end{tabular}

(1)


(1962), and Blodi, Reuling, and Sornson (1965); in addition it was observed in Case 2 of the present report. Anaplasia is also a characteristic of most malignant tumours and it was the absence of such a feature in the neoplasm described by Blodi and his colleagues (1965) that led them to regard their case as benign. Essentially, however, the terms benign and malignant relate to the expected behaviour of the tumour, in which case functional properties such as invasiveness are more significant than morphological characteristics. That choroidal invasion can be a forerunner of extraocular extension is demonstrated in the cases reported by Griffith ( I 894), Märtens (I92 I), and Bietti (I93I), wherein the neoplastic cells spread along the ciliary nerves and vascular channels of the sclera. Consequently it would seem proper to regard extension beyond Bruch's membrane as indicative of malignancy.

There is some evidence that benign and possibly malignant neoplasms of the retinal pigment epithelium can stem from hyperplastic growths, as both Greer (1952) and Reese (1963) stress, in which case attempts to distinguish between such neoplastic and reactive processes is often necessarily arbitrary. It is questionable, however, whether it is right to use the term hyperplasia in the absence of an apparent stimulus and, for this reason, it would seem appropriate to regard cases such as the first of the two reported by Theobald, Floyd, and Kirk (1958) and that reported by Machemer (1964) as benign neoplasms. The cases described by Stow (1949), Kornblueth and Behar (1960), and Spiers and Jensen (1963) were also reported as examples of hyperplasia; but because of the adenomatous

\begin{tabular}{|c|c|c|c|c|c|c|c|}
\hline \multicolumn{4}{|c|}{ ion } & \multirow{2}{*}{$\begin{array}{l}\text { Associated } \\
\text { inflammation }\end{array}$} & \multirow{2}{*}{$\begin{array}{l}\text { Melanin } \\
\text { formation }\end{array}$} & \multirow{2}{*}{$\begin{array}{l}\text { Glandular } \\
\text { pattern }\end{array}$} & \multirow{2}{*}{ Survival } \\
\hline$a$ & Choroid & Sclera & Optic nerve & & & & \\
\hline & ? & - & - & + & - & - & Alive and well at $5 \frac{1}{2}$ yrs \\
\hline & + & - & - & - & + & + & Alive and well at $9 \mathrm{mths}$ \\
\hline & + & + & - & - & + & + & Dead at I yr \\
\hline & + & + & + & + & \pm & + & Dead at $6 \mathrm{mths}$ \\
\hline & + & + & - & - & + & + & Dead at $7 \frac{1}{2} \mathrm{mths}$ \\
\hline & + & - & $?$ & - & + & + & \\
\hline & - & - & - & + & - & + & \\
\hline & - & - & - & + & - & + & Alive and well at $16 \mathrm{yrs}$ \\
\hline & + & - & + & + & + & + & \\
\hline & - & - & - & - & + & - & \\
\hline & + & - & - & - & + & - & Alive and well at $\mathrm{x} \frac{1}{2} \mathrm{yrs}$ \\
\hline & - & - & - & - & + & - & \\
\hline & - & - & - & + & + & + & \\
\hline & - & - & + & - & + & + & \\
\hline & + & - & - & - & + & - & Alive and well at $4 \mathrm{yrs}$ \\
\hline & - & - & - & + & - & + & \\
\hline & - & - & - & - & + & - & \\
\hline & + & - & - & - & - & + & \\
\hline & - & - & - & - & + & - & \\
\hline
\end{tabular}

: tumour are strongly suggestive of an epithelial origin

1 pigment epithelium and depicts it as such in his monograph on ocular tumours (Reese, 1963) 
nature of the proliferation and the indeterminate borderland between a purely reactive process and true neoplasia, especially in the context of the retinal pigment epithelium, there would again seem to be some justification for regarding these cases as benign neoplasms.

Applying these criteria, ten of the cases listed in Table I were malignant and nine were benign neoplasms of the retinal pigment epithelium.

The analysis provided in Table II suggests that malignancy is more common in patients $\frac{0}{\sigma}$ over the age of $4^{0}$ years, though the possibility that the age differential simply reflects the $\stackrel{\circ}{0}$ duration of the neoplastic process, and hence of opportunity for invasion to occur, cannot ${ }^{\circ}$ be entirely overlooked. Pre-existing and concurrent inflammation does not appear to be $\vec{\circ}$ an important stimulus to malignancy; nor does sex seem to be a factor. Melanin forma- $\vec{a}$ tion on the other hand was present in all but one of the malignant tumours whereas it was absent from almost half the benign lesions: a finding which is reminiscent of the worse prognosis sometimes associated with the more heavily pigmented melanomata of choroidal origin (Benjamin, Cumings, Goldsmith, and Sorsby, I948; Wilder and Paul, I951). Differentiation to an adenomatous architecture characterized by the formation of tubular elements was also more common in the malignant tumours.

Table II Comparison of 19 published benign and malignant tumours of retinal pigment epithelium

\begin{tabular}{|c|c|c|c|c|}
\hline \multicolumn{2}{|l|}{ Tumour } & \multirow{2}{*}{$\frac{\text { Benign }}{7}$} & \multirow{2}{*}{$\begin{array}{l}\text { Malignant } \\
3 \\
7\end{array}$} & \multirow{2}{*}{$\begin{array}{c}\text { Total } \\
\text { ro } \\
9\end{array}$} \\
\hline Age (yrs) & $\begin{array}{r}<40 \\
>40 \\
\end{array}$ & & & \\
\hline Sex & $\begin{array}{l}\mathbf{M} \\
\mathbf{F}\end{array}$ & $\begin{array}{l}5 \\
4\end{array}$ & $\begin{array}{l}4 \\
6\end{array}$ & $\begin{array}{r}9 \\
\text { 10 }\end{array}$ \\
\hline Associated Inflammation & $\begin{array}{l}\text { Present } \\
\text { Absent }\end{array}$ & $\begin{array}{l}5 \\
4\end{array}$ & $\begin{array}{l}2 \\
8\end{array}$ & $\begin{array}{r}7 \\
12\end{array}$ \\
\hline Pigment Formation & $\begin{array}{l}\text { Present } \\
\text { Absent }\end{array}$ & $\begin{array}{l}5 \\
4\end{array}$ & $\begin{array}{l}9 \\
\mathrm{I}\end{array}$ & $\begin{array}{r}14 \\
5 \\
\end{array}$ \\
\hline Glandular Differentiation & $\begin{array}{l}\text { Present } \\
\text { Absent }\end{array}$ & $\begin{array}{l}4 \\
5\end{array}$ & $\begin{array}{l}8 \\
2\end{array}$ & $\begin{array}{r}12 \\
7\end{array}$ \\
\hline
\end{tabular}

In comparatively few of the published reports is there any follow-up data. It would appear nevertheless that where there has been extraocular extension the prognosis is likely to be poor. Thus, Bietti's patient died 7 months after enucleation with local recurrence and possibly hepatic metastases (Bietti, I93I), while the patient described by Schuster (1928) died from pigment-containing adenocarcinomatous metastases thought to have originated from a primary tumour in the retinal epithelium. The patient reported by Märtens (I92 I) developed a fatal septic endocarditis 6 months after operation and at necropsy showed evidence of residual tumour around the optic nerve stump and chiasma, and a patient described by Griffith (1894) died one year after enucleation with recurrence 0 in the orbit and maxilla. In the absence of extraocular extension at the time of enuclea- $C$ tion, however, the prognosis would appear to be excellent, for in none of the presumed malignant cases reviewed has there been any subsequent report of recurrence or metastasis. Similarly, and as might be expected, the two patients with benign adenomata in whom the postoperative period has been documented were alive and well after 5 years (Case I of the present report) and 16 years (Case 3 originally described by Greer, I952) respectively. 


\section{Summary}

A review of tumours of the retinal pigment epithelium, including a description of two new cases, leaves little doubt that malignancy may and does occur. Fortunately this is usually of a low grade and, in the absence of apparent invasion beyond the choroid or lamina cribrosa at the time of enucleation, a favourable prognosis would seem to be warranted. Neoplasms regarded as malignant were more common in patients over the age of 40 years and in general showed active melanin formation and a variable degree of glandular differentiation, and, though occasionally being superimposed on an inflammatory background, frequently appeared to have arisen spontaneously.

\section{References}

Benjamin, B., Cumings, J. N., goldsmith, A. J. B., and sorsby, A. (1948) Brit. F. Ophthal., 32, 729 Berenblum, I. (1970) In "General Pathology", 4th ed., ed. H. W. Florey, p. 655. Lloyd-Luke,

London

BIETtı, G. (I93I) Klin. Mbl. Augenheilk., 87, 459

BLODI, F. C., REULING, F. H., and sornson, E. T. (1965) Arch. Ophthal. (Chicago), 73, 353

CURY, D., LUCic, H., and IRVINe, A. R., JR. (1959) Amer. F. Ophthal., 47, no. 5, pt 2, p. 202

DUKE, J. R., and MAUMENEe, A. E. (I959) Ibid., 47, 3 I I

FAIR, J. R. (1958) Ibid., 45, 495

GREER, C. H. (1952) Trans. ophthal. Soc. U.K., 72, 265

GRIFFITH, J. (1894) Ibid., I4, I6o

KORNBLUETH, W., and BeHAR, A. J. (1960) Israel med. F., 19, 237

Kraus, E. (1968) v. Graefes Arch. Ophthal., r75, 75

KURZ, G. H., and zimmerman, L. E. (1962) Int. Ophthal. Clin., 2, 44I

MACHEMER, R. (1964) v. Graefes Arch. Ophthal., 167, 284

märtens, м. (1921) Arch. Augenheilk., 89, I

Parsons, J. H. (1905) "The Pathology of the Eye", vol. 2, p. 650. Hodder and Stoughton, London REESE, A. B. (1963) "Tumours of the Eye", 2nd ed., p. 46. Hoeber, New York

ReIN, G. (1960) v. Graefes Arch. Ophthal., 16r, 519

RøNNE, G. (1945) Acta ophthal. (Kbh.), 23, 382

SGHUSTER, H. (1928) Virchows Arch. path. Anat., 269, 97

SPIERS, F., and JENSEN, O. A. (1963) Acta ophthal. (Kbh.), 4I, 722

stow, м. N. (1949) Trans. Amer. Acad. Ophthal. Otolaryng., 53, 674

THEOBAlD, G. D., FlOYD, G., and KIRK, H. Q. (1958) Amer. F. Ophthal., 45, no. 4, pt 2, p. 235

WILDER, H. C., and PAUL, E. v. (195I) Mil. Surg., rog, 370 